\title{
Reciprocal responses to dietary diacylglycerol of hepatic enzymes of fatty acid synthesis and oxidation in the rat
}

\author{
BY MASAKAZU MURATA ${ }^{1}$, TAKASHI IDE ${ }^{1 *}$ AND KENJI HARA $^{2}$ \\ ${ }^{1}$ Laboratory of Nutrition Biochemistry, Division of Physiology and Nutrition, National Food Research \\ Institute, Ministry of Agriculture, Forestry and Fisheries, 2-1-2 Kannondai, Tsukuba Science City, \\ Ibaraki 305, Japan \\ ${ }^{2}$ Kao Co. Ltd., 2606 Ichikai, Haga, Tochigi 321-34, Japan
}

(Received 4 December 1995 - Revised 7 May 1996 - Accepted 31 May 1996)

\begin{abstract}
The activities of hepatic enzymes of fatty acid synthesis and oxidation were compared in rats fed on diacylglycerol and triacylglycerol. In the first trial, rats were fed on diacylglycerol or triacylglycerol (rapeseed oil) for $14 \mathrm{~d}$. The diacylglycerol preparation contained $65.2 \mathrm{~g}$ and $32.6 \mathrm{~g}$ fatty acids $/ 100 \mathrm{~g}$ total fatty acids as 1,3-species and 1,2-species respectively. Fatty acid compositions of these dietary lipids were similar. Dietary acylglycerols were added to experimental diets to provide the same amounts of fatty acids $(93.9 \mathrm{~g} / \mathrm{kg}$ diet). Dietary diacylglycerol compared with triacylglycerol significantly reduced the concentrations of serum and liver triacylglycerol. The activities of enzymes of fatty acid synthesis (fatty acid synthetase, glucose 6-phosphate dehydrogenase (EC 1.1.1.49) and malic enzyme (EC 1.1.1.40)) were significantly lower in rats fed on diacylglycerol than in those fed on triacylglycerol. In contrast, the rates of mitochondrial and peroxisomal oxidation of palmitoylCoA in liver homogenates were higher in rats fed on diacylglycerol than in those fed on triacylglycerol. In the second trial, varying amounts of dietary triacylglycerol were replaced by diacylglycerol while the dietary fatty acid content was maintained $(93.9 \mathrm{~g} / \mathrm{kg}$ diet). After $21 \mathrm{~d}$ of the feeding period the significant reductions in serum and liver triacylglycerol levels were confirmed in groups of rats fed on the diets in which diacylglycerol supplied more than $65.8 \mathrm{~g}$ fatty acids $/ \mathrm{kg}$ diet $(65.8$ and $93.9 \mathrm{~g} / \mathrm{kg})$. Reductions in the activities of enzymes of fatty acid synthesis and increases in palmitoyl-CoA oxidation rates by both mitochondrial and peroxisomal pathways were also apparent when diacylglycerol replaced triacylglycerol in diets to supply more than $65.8 \mathrm{~g}$ fatty acid $/ \mathrm{kg}$. Increasing dietary levels of diacylglycerol also progressively increased the activities of enzymes involved in the $\beta$-oxidation pathway (carnitine palmitoyltransferase (EC 2.3.1.21), acyl-CoA dehydrogenase (EC 1.3.99.3), acyl-CoA oxidase (EC 1.3.3.6), enoyl-CoA hydratase (EC 4.2.1.17), 3hydroxyacyl-CoA dehydrogenase (EC 1.1.1.35), 2,4-dienoyl-CoA reductase $(E C 1.3 .1 .34)$ and $\Delta^{3}, \Delta^{2}-$ enoyl-CoA isomerase $(E C$ 5.3.3.8)) in the liver. These results suggest that alteration of fatty acid metabolism in the liver is a factor responsible for the serum triacylglycerol-lowering effect of dietary diacylglycerol.
\end{abstract}

Diacylglycerol: Fatty acid synthesis: Fatty acid oxidation: Serum triacylglycerol

In an initial step of the digestion and absorption of dietary triacylglycerol, lingual or pancreatic lipase (EC 3.1.1.3) cleaves the fatty acid at the 1 or 3 position of the lipid molecule to form diacylglycerol. As diacylglycerols which occur during the digestive process of triacylglycerol are 1,2 and 2,3-species but not 1,3-species, it is expected that ingestion of 1,3-diacylglycerol compared with triacylglycerol may exert a different effect on lipid metabolism in the organism. In fact, we previously demonstrated that dietary

*For reprints. 
diacylglycerol mainly composed of 1,3-species compared with triacylglycerol (rapeseed oil) significantly reduced serum triacylglycerol concentration in rats (Hara et al. 1993). We also showed that intragastric infusion of diacylglycerol compared with triacylglycerol significantly retarded the lymphatic transport of triacylglycerol as chylomicrons in rats (Murata et al. 1994). The impairment of chylomicron assembly and subsequent release into the circulation through the lymph is therefore considered to be a factor responsible for the serum triacylglycerol-lowering effect of dietary diacylglycerol. A plausible alternative factor modifying the serum triacylglycerol concentration is the change in the rates of fatty acid synthesis and oxidation in the liver. It has been clearly demonstrated that the alterations in the rates of fatty acid synthesis (Windmueller \& Spaeth, 1967; Brunengraber $e t$ al. 1973) and oxidation, either in the mitochondrial (Ide \& Ontko, 1981) or the peroxisomal pathway (Ide et al. 1982), modify the availability of fatty acids for triacylglycerol synthesis and in turn alter the VLDL production by the liver. We hypothesized that dietary diacylglycerol not only alters chylomicron production but also may modify the hepatic metabolism of fatty acid and thus lower serum triacylglycerol concentration in the rat. As the effect of dietary diacylglycerol on the metabolism of fatty acid in the liver is not known, we compared the effects of dietary diacylglycerol and triacylglycerol on the activities of hepatic enzymes in fatty acid synthesis and oxidation pathways in the present study.

\section{EXPERIMENTAL}

\section{Materials}

The diacylglycerol preparation was synthesized enzymically by esterifying glycerol with fatty acids from rapeseed oil using the reverse reaction of 1,3-specific lipase, purified using silicic acid chromatography (Barron \& Hanahan, 1958; Hara et al. 1993; Murata et al. 1994) and analysed (Karlson \& Pascher, 1971; Hara et al. 1993; Murata et al. 1994) as described previously. The majority of fatty acids in rapeseed oil exist as triacylglycerol while fatty acids in the diacylglycerol preparation were recovered mainly in 1,3$(65.2 \mathrm{~g} / 100 \mathrm{~g}$ total fatty acids in the preparation) and, to a lesser extent, in 1,2diacylglycerol $(32.6 \mathrm{~g} / 100 \mathrm{~g}$ total fatty acid in the preparation) fractions (Table 1). We synthesized diacylglycerol using 1,3-specific lipase, therefore 1,2-diacylglycerol was considered to be the product of acyl migration. The fatty acid composition of the diacylglycerol preparation was indistinguishable from that of rapeseed oil. The fatty acid content of diacylglycerol was $891 \mathrm{~g} / \mathrm{kg}$ and that of rapeseed oil was $939 \mathrm{~g} / \mathrm{kg}$. $\left[1-{ }^{14} \mathrm{C}\right]$ Palmitic acid was purchased from Amersham International, Amersham, Bucks. $\left[1-{ }^{14} \mathrm{C}\right]$ Palmitoyl-CoA and non-radiolabelled palmitoyl-CoA were prepared according to the method of Kawaguchi et al. (1981). Acetyl-CoA was prepared by acylating CoA with acetic anhydride, acetoacetyl-CoA using diketene and crotonyl-CoA using crotonic anhydride. Sorboyl-CoA and trans-3-hexenoyl-CoA were prepared using the mixed anhydride method (Goldman \& Vagelos, 1961). Malonyl-CoA was purchased from Sigma Chemical Co., St. Louis, MO, USA. Bovine serum albumin fraction V (essential-fatty-acidfree) was the product of Boehringer Mannheim, Gmbh, Germany.

\section{Animals and diets}

Male Sprague-Dawley rats obtained from Charles River Japan, Kanagawa, Japan were housed individually in a room with controlled temperature $\left(20-22^{\circ}\right)$, humidity $(55-65 \%)$ and lighting (light on from 0.700 to 19.00 hours), and fed on a commercial non-purified 
Table 1. Fatty acid distributions and compositions ( $\mathrm{g} / 100 \mathrm{~g}$ total fatty acids) of dietary triacylglycerol and diacylglycerol

\begin{tabular}{ccc}
\hline \hline & Triacylglycerol & Diacylglycerol \\
\hline Fatty acid distribution & & \\
Triacylglycerol & $98 \cdot 8$ & 0.4 \\
1,2-Diacylglycerol & 0.4 & 32.6 \\
1,3-Diacylglycerol & $0 \cdot 8$ & 65.2 \\
Monoacylglycerol & - & 1.7 \\
Fatty acid composition & $3 \cdot 8$ & 4.5 \\
$16: 0$ & 0.4 & 0.1 \\
$16: 1$ & $1 \cdot 3$ & 1.5 \\
$18: 0$ & 60.5 & 60.7 \\
$18: 1$ & $22 \cdot 3$ & 23.8 \\
$18: 2$ & 11.6 & 10.9 \\
$18: 3$ &
\end{tabular}

diet (Type NMF, Oriental Yeast Co., Tokyo, Japan). After $7 \mathrm{~d}$ of acclimatization to the housing conditions, rats were fed on purified experimental diets. The basal composition of the experimental diet was $(\mathrm{g} / \mathrm{kg})$ : casein 200 , maize starch 150 , cellulose 20 , mineral mixture 35, vitamin mixture 10, DL-methionine 3 , choline bitartrate 2 and sucrose to $1 \mathrm{~kg}$. The compositions of the mineral and vitamin mixtures were those recommended by the American Institute of Nutrition (1977). Dietary lipids were added to the diets to provide the same amount of fatty acids $(93.9 \mathrm{~g} / \mathrm{kg}$ diet). In the first experiment, rats were randomly divided into two groups consisting of eight animals each and fed on experimental diets containing $100 \mathrm{~g}$ triacylglycerol $/ \mathrm{kg}$ (rapeseed oil) and $105 \mathrm{~g}$ diacylglycerol $/ \mathrm{kg}$ for $14 \mathrm{~d}$. In the second experiment, four groups of rats consisting of seven animals each were fed on diets containing varying amounts of the diacylglycerol preparation for $21 \mathrm{~d}$. The diet without diacylglycerol contained $93.9 \mathrm{~g}$ fatty acids $/ \mathrm{kg}$ of the diet as rapeseed oil. Varying amounts of diacylglycerol preparation were added to the experimental diet in lieu of rapeseed oil in amounts so that this dietary lipid provided $28.2,65.7$ and $93.9 \mathrm{~g}$ fatty acids $/ \mathrm{kg}$ of the diet while maintaining constant dietary fatty acid levels. We followed the guidelines of our institute for care and use of laboratory animals. Average body weights of animals at initiation of the experiments were 153 (SD 11) g for Expt 1 and 118 (SD 11) g for Expt 2.

\section{Enzyme assays}

At the termination of the experimental period, rats were anaesthetized using diethyl ether and killed by bleeding from the abdominal aorta, after which livers were quickly excised. About $3 \mathrm{~g}$ of each liver was homogenized with 7 volumes of $0.25 \mathrm{M}$-sucrose and centrifuged at $500 \mathrm{~g}$ for $10 \mathrm{~min}$. The supernatant fraction was recentrifuged at $9000 \mathrm{~g}$ for $10 \mathrm{~min}$ to isolate mitochondria. The mitochondrial fraction was washed twice with $0.25 \mathrm{M}$ sucrose containing $1 \mathrm{mM}-\mathrm{EDTA}$ and $3 \mathrm{mM}-\mathrm{Tris}-\mathrm{HCl}(\mathrm{pH} 7.0)$ and finally suspended in the same medium to give a protein concentration of $20-25 \mathrm{mg} / \mathrm{ml}$. Glucose 6-phosphate dehydrogenase (EC 1.1.1.49) (Kelley \& Kletzien, 1984), malic enzyme (EC 1.1.1.40) (Hsu \& Lardy,1969) and fatty acid synthetase (Kelley et al. 1986) activities were measured in the $9000 \mathrm{~g}$ supernatant fraction of liver homogenates (Ide et al. 1992). The rates of mitochondrial and peroxisomal oxidation of fatty acids were measured using the $500 \mathrm{~g}$ supernatant fraction of liver homogenates according to the method described by Mannaerts 
et al. (1979). The assay mixture for mitochondrial activity contained $4 \mathrm{mM}-\mathrm{ATP}, 0.5 \mathrm{mM}-$ L-carnitine, $0.05 \mathrm{mM}-\mathrm{CoA}, 2 \mathrm{mM}$-dithiothreitol, $7.2 \mathrm{mg} / \mathrm{ml}$ albumin (fatty-acid-free), $0.2 \mathrm{mM}-\left[1-{ }^{14} \mathrm{C}\right] \mathrm{palmitoyl}-\mathrm{CoA}(0.0074 \mathrm{MBq} / \mu \mathrm{mol})$ and $0.1 \mathrm{ml}$ of the $500 \mathrm{~g}$ supernatant fraction (1.3-1.6 mg protein) in modified Krebs-Henseleit bicarbonate buffer (pH 7.4) (Mannaerts et al. 1979). Assays conducted in the presence of $2 \mathrm{mM}-\mathrm{KCN}$ served as blanks. The mixture for the assay of peroxisomal activity contained $4 \mathrm{mM}-\mathrm{ATP}, 0.5 \mathrm{mM}-\mathrm{CoA}$, $2 \mathrm{mM}-\mathrm{NAD}, \quad 2 \mathrm{mM}$-dithiothreitol, $\quad 2 \mathrm{mM}-\mathrm{KCN}, \quad 0.2 \mathrm{mM}-\left[1-{ }^{14} \mathrm{C}\right]$ palmitoyl-CoA $(0.0074 \mathrm{MBq} / \mu \mathrm{mol})$ and $0.05 \mathrm{ml}$ of the $500 \mathrm{~g}$ supernatant fraction $(0.65-0.8 \mathrm{mg}$ protein) in the modified Krebs-Henseleit bicarbonate buffer ( $\mathrm{pH} 7.4)$. The presence of albumin is obligatory to measure mitochondrial activity while it severely inhibits peroxisomal oxidation of palmitoyl-CoA (Mannaerts et al. 1979). We therefore did not include albumin for the assay of peroxisomal activity. Assays conducted in the absence of the enzyme source served as blanks for peroxisomal activities. The final volumes of the mixture were $2.5 \mathrm{ml}$ for both the assays of mitochondrial and peroxisomal activities. The rates of mitochondrial and peroxisomal $\beta$-oxidation of palmitoyl-CoA were assayed under an atmosphere of $\mathrm{CO}_{2}-\mathrm{O}_{2}(5: 95, \mathrm{v} / \mathrm{v})$ for $10 \mathrm{~min}$ and terminated by pouring the mixture into test-tubes containing $0.625 \mathrm{ml} 3 \mathrm{M}$-perchloric acid. After letting the mixture stand for at least $15 \mathrm{~min}$ in an ice bath, it was centrifuged at $2500 \mathrm{~g}$ for $10 \mathrm{~min}$ and $2 \mathrm{ml}$ of the supernatant fraction was assayed for radioactivity by liquid scintillation counting. The supernatant fraction obtained after centrifugation of liver homogenates at $500 \mathrm{~g}$ for $10 \mathrm{~min}$ was used for the measurements of the activities of fatty acid oxidation enzymes except for carnitine palmitoyltransferase ( $E C$ 2.3.1.21) and acyl-CoA dehydrogenase ( $E C$ 1.3.99.3). Because of the consideration that carnitine palmitoyltransferase and acyl-CoA dehydrogenase are primarily mitochondrial enzymes (Schulz, 1991) and of the fact that the assays using the $500 \mathrm{~g}$ supernatant fraction as the enzyme source gave extremely high blank values, these enzymes were assayed in isolated mitochondrial fraction as an enzyme source. Carnitine palmitoyltransferase I activity was determined radiochemically using freshly isolated mitochondria as an enzyme source according to the method of Bremer $e t$ al. (1985). Carnitine palmitoyltransferase activity was also measured spectrophotometrically in the freeze-thawed preparation of isolated mitochondria solubilized with Triton $\mathrm{X}-100$ according to the method of Markwell et al. (1973) as described elsewhere (Ide et al. 1987). The value obtained presumably represents the sum of the activities of carnitine palmitoyltransferase I and II. Acyl-CoA dehydrogenase activity was measured in isolated mitochondria according to the method described by Dommes \& Kunau (1976) except that phenazine methosulphate was used as a primary electron acceptor. Acyl-CoA oxidase (EC 1.3.3.6) activity was measured in the $500 \mathrm{~g}$ supernatant fraction of liver homogenates as described elsewhere (Hashimoto et al. 1981; Ide et al. 1987). Palmitoyl-CoA was used as a substrate for carnitine palmitoyltransferase, acyl-CoA dehydrogenase and acyl-CoA oxidase assays. Crotonyl-CoA was used as the substrate for enoyl-CoA hydratase (EC 4.2.1.17) (Osumi \& Hashimoto, 1979a), acetoacetyl-CoA for 3-hydroxyacyl-CoA dehydrogenase (EC 1.1.1.35) (Osumi \& Hashimoto, 1979b), sorboyl-CoA for 2,4dienoyl-CoA reductase (EC 1.3.1.34) (Kunau \& Dommes, 1978) and trans-3-hexenoylCoA for $\Delta^{3}, \Delta^{2}$-enoyl-CoA isomerase (EC 5.3.3.8) (Palosaari et al. 1990) in assaying the activities. Activities of marker enzymes for cell organelles including succinate dehydrogenase ( $E C$ 1.3.99.1) (mitochondria) (Veeger et al. 1969), catalase (EC 1.11.1.6) (peroxisomes) (Cohen et al. 1970), lactate dehydrogenase (EC 1.1.1.27) (cytosols) (Wahlefeld, 1985) and NADPH-cytochrome $\mathrm{C}$ reductase (nicrosomes) (Omura \& Takesue, 1970) were determined in the $500 \mathrm{~g}$ supernatant fraction of liver homogenates. The rates of mitochondrial and peroxisomal oxidation of fatty acids and carnitine 
palmitoyltransferase I activity were measured on the day of slaughter using non-freezethawed enzyme preparations. Other enzymes were assayed in the enzyme preparations stored at $-40^{\circ}$ for up to $10 \mathrm{~d}$.

\section{Lipid analyses}

Liver and serum lipids were extracted and purified (Folch et al. 1957). Triacylglycerol, phospholipid and cholesterol contents in the extracts were determined as described previously (Hara et al. 1993). Triacylglycerol and phospholipid in the liver lipid extract were separated by TLC and the fatty acid compositions of these lipid molecules were determined using a gas-liquid chromatograph (Ide et al. 1978).

\section{Statistical analyses}

Examinations of significant differences of means with a pooled estimate of variance for Expts 1 and 2 were established appropriately according to the methods of Snedecor \& Cochran (1989) for the comparison of two samples (Expt 1) and for one-way classifications (Expt 2) respectively as detailed previously (Ide et al. 1994).

\section{RESULTS}

Rats were fed on diets containing $93.9 \mathrm{~g}$ fatty acids/ $\mathrm{kg}$ as triacylglycerol (rapeseed oil) or the diacylglycerol preparation for $14 \mathrm{~d}$ in Expt 1 . No significant difference in body weights was observed at the termination of the experimental period (292 (SD 20) and 300 (SD 14) g for rats fed on the triacylglycerol and diacylglycerol diets respectively). Dietary diacylglycerol did not affect amounts of experimental diets consumed during the $14 \mathrm{~d}$ (345 (SD 62) and 334 (SD 54) $g$ for rats fed on the triacylglycerol and diacylglycerol diets respectively). The weights of livers excised at the termination of the experimental period were the same for rats fed on the triacylglycerol diet (55.7 (SD 6.5) $\mathrm{g} / \mathrm{kg}$ body weight) and the diacylglycerol diet $(51.9$ (SD 11.0) $\mathrm{g} / \mathrm{kg}$ body weight). In the experiment where rats were fed on diets varying in diacylglycerol content for $21 \mathrm{~d}$ (Expt 2), body weights at the time of slaughter were indistinguishable among the groups (288-290 g). Cumulative values for the amount of diet consumed during the experimental period ranged from 443 to $452 \mathrm{~g}$ with no significant differences among the groups. Also, no differences in the weights of livers excised at the termination of the experimental period $(49.5-53.2 \mathrm{~g} / \mathrm{kg}$ body weight) were observed among the four groups.

The potency of dietary diacylglycerol in reducing the serum triacylglycerol concentration demonstrated in a previous study (Hara et al. 1993) was confirmed in the present study (Table 2). Thus, the serum triacylglycerol concentration was significantly lower in rats fed on the diet containing $93.9 \mathrm{~g}$ fatty acids/ $\mathrm{kg}$ exclusively as diacylglycerol for $14 \mathrm{~d}$ than in those fed on the diet containing the same dietary level of fatty acids in the form of triacylglycerol (Expt 1). The serum triacylglycerol concentration decreased as the dietary level of diacylglycerol increased and values in the rats fed on the diets containing 65.7 and $93.8 \mathrm{~g}$ fatty acids in the form of diacylglycerol became significantly lower than those in the animals fed on a diet without diacylglycerol (Expt 2). However, dietary diacylglycerol was in no way effective in altering the serum concentrations of phospholipid and cholesterol in either Expt 1 or 2 . Diets containing diacylglycerol as the dietary lipid were also effective in reducing the triacylglycerol concentration in the liver in both Expts 1 and 2 . The replacement of triacylglycerol with diacylglycerol to supply more than $65.7 \mathrm{~g}$ 
Table 2. Concentrations of lipid components in the serum $(\mathrm{mg} / \mathrm{ml})$ and liver $(\mathrm{mg} / \mathrm{g})$ of rats fed on diets containing different proportions of diacylglycerol and triacylglycerol*

(Mean values and standard deviations)

\begin{tabular}{|c|c|c|c|c|c|c|c|}
\hline \multirow{3}{*}{$\begin{array}{l}\text { Dietary fatty acids } \\
\text { as diacylglycerol/ } \\
\text { triacylglycerol } \\
\text { (g/kg diet) }\end{array}$} & \multirow[b]{3}{*}{$n$} & \multicolumn{6}{|c|}{ Lipid components } \\
\hline & & \multicolumn{2}{|c|}{ Triacylglycerol } & \multicolumn{2}{|c|}{ Phospholipid } & \multicolumn{2}{|c|}{ Cholesterol } \\
\hline & & Mean & SD & Mean & SD & Mean & SD \\
\hline \multicolumn{8}{|l|}{ Expt 1} \\
\hline \multicolumn{8}{|l|}{ Serum lipids } \\
\hline $0 / 93.9$ & 8 & $3 \cdot 13^{b}$ & $1 \cdot 28$ & $2 \cdot 18^{\mathrm{a}}$ & 0.57 & $1.02^{a}$ & 0.14 \\
\hline $93 \cdot 9 / 0$ & 8 & $1.89^{\mathrm{a}}$ & 0.53 & $2 \cdot 22^{\mathrm{a}}$ & 0.40 & $1.03^{a}$ & 0.08 \\
\hline Pooled SD & & \multicolumn{2}{|c|}{0.96} & \multicolumn{2}{|c|}{0.49} & \multicolumn{2}{|c|}{0.11} \\
\hline df & & \multicolumn{2}{|c|}{14} & \multicolumn{2}{|c|}{14} & \multicolumn{2}{|c|}{14} \\
\hline \multicolumn{8}{|l|}{ Liver lipids } \\
\hline $0 / 93.9$ & 8 & $44 \cdot 7^{b}$ & $5 \cdot 3$ & $28.8^{\mathrm{a}}$ & $2 \cdot 0$ & $2 \cdot 39^{\mathrm{a}}$ & 0.61 \\
\hline $93.9 / 0$ & 8 & $34 \cdot 0^{\mathrm{a}}$ & $6 \cdot 3$ & $28.4^{\mathrm{a}}$ & 1.9 & $4.85^{b}$ & 0.70 \\
\hline Pooled SD & & \multicolumn{2}{|c|}{$5 \cdot 8$} & \multicolumn{2}{|c|}{1.9} & \multicolumn{2}{|c|}{0.66} \\
\hline df & & \multicolumn{2}{|c|}{14} & \multicolumn{2}{|c|}{14} & \multicolumn{2}{|c|}{14} \\
\hline \multicolumn{8}{|l|}{ Expt 2} \\
\hline \multicolumn{8}{|l|}{ Serum lipids } \\
\hline $0 / 93.9$ & 7 & $3 \cdot 71^{\mathrm{c}}$ & 0.53 & $2 \cdot 22^{\mathrm{a}}$ & 0.58 & $1.04^{\mathrm{a}}$ & 0.11 \\
\hline $28 \cdot 2 / 65 \cdot 7$ & 7 & $3.60^{\mathrm{c}}$ & 0.28 & $2 \cdot 07^{\mathrm{a}}$ & 0.21 & $1.04^{\mathrm{a}}$ & 0.10 \\
\hline $65 \cdot 7 / 28 \cdot 2$ & 7 & $2 \cdot 86^{\mathrm{b}}$ & 0.15 & $2.03^{a}$ & 0.05 & $1.00^{\mathrm{a}}$ & 0.08 \\
\hline $93.9 / 0$ & 7 & $2 \cdot 07^{a}$ & 0.11 & $2 \cdot 01^{\mathrm{a}}$ & 0.18 & $1 \cdot 04^{\mathrm{a}}$ & 0.11 \\
\hline Pooled SD & & \multicolumn{2}{|c|}{0.34} & \multicolumn{2}{|c|}{0.35} & \multicolumn{2}{|c|}{0.11} \\
\hline df & & \multicolumn{2}{|c|}{24} & \multicolumn{2}{|c|}{24} & \multicolumn{2}{|c|}{24} \\
\hline \multicolumn{8}{|l|}{ Liver lipids } \\
\hline $0 / 93.9$ & 7 & $31.4^{b}$ & $5 \cdot 18$ & $22 \cdot 7^{\mathrm{a}}$ & $2 \cdot 88$ & $2.08^{a}$ & 0.52 \\
\hline $28 \cdot 2 / 65 \cdot 7$ & 7 & $33 \cdot 2^{b}$ & 4.54 & $23 \cdot 3^{a}$ & 2.41 & $2.03^{\mathrm{a}}$ & 0.33 \\
\hline $65 \cdot 7 / 28 \cdot 2$ & 7 & $27.5^{\mathrm{a}}$ & 3.64 & $22 \cdot 6^{\mathrm{a}}$ & $2 \cdot 68$ & $2.08^{a}$ & 0.31 \\
\hline $93.9 / 0$ & 7 & $25 \cdot 5^{a}$ & 2.96 & $22 \cdot 5^{\mathrm{a}}$ & 3.47 & $2.93^{\mathrm{b}}$ & 0.27 \\
\hline Pooled SD & & \multicolumn{2}{|c|}{$4 \cdot 17$} & & & & \\
\hline$d f$ & & & & & & & \\
\hline
\end{tabular}

${ }^{\text {a,b,c }}$ Mean values within a column, within each experiment, with unlike superscript letters were significantly different, $P<0.05$.

*For details of diets and procedures, see pp. 108-111.

fatty acids in the diet was required to decrease triacylglycerol concentration in the liver effectively (Expt 2). In contrast, the concentration of liver cholesterol was significantly higher in rats fed on acylglycerol exclusively in the form of diacylglycerol than in animals fed on a diet devoid of diacylglycerol, in both Expts 1 and 2.

Compared with triacylglycerol, dietary diacylglycerol reduced the activities of various enzymes of fatty acid synthesis in both Expts 1 and 2 (Table 3). Activities decreased as the dietary levels of diacylglycerol increased (Expt 2). Even a diet which supplied $28.2 \mathrm{~g}$ fatty acids $/ \mathrm{kg}$ diet in the form of diacylglycerol compared with the diet without diacylglycerol was effective in significantly reducing the activity of glucose 6-phosphate dehydrogenase. The replacement of triacylglycerol by diacylglycerol to supply more than $65.7 \mathrm{~g}$ of fatty acid in the diet was required to reduce the activities of malic enzyme and fatty acid synthetase.

The rate of palmitoyl-CoA oxidation through the mitochondrial pathway measured using the $500 \mathrm{~g}$ supernatant fraction of rat liver homogenates as an enzyme source was about $25 \%$ higher in rats fed on diacylglycerol than in those fed on triacylglycerol in Expt 1 (Table 4). The rate of peroxisomal oxidation of the palmitoyl-CoA substrate in this 
Table 3. Activities of enzymes involved in fatty acid synthesis (nmol/min per $\mathrm{mg}$ protein) in the livers of rats fed on diets containing different proportions of diacylglycerol and triacylglycerol*

(Mean values and standard deviations)

\begin{tabular}{|c|c|c|c|c|c|c|c|c|}
\hline \multirow{3}{*}{$\begin{array}{l}\text { Dietary fatty acids } \\
\text { as diacylglycerol/ } \\
\text { triacylglycerol } \\
(\mathrm{g} / \mathrm{kg} \text { diet })\end{array}$} & \multirow[b]{3}{*}{$n$} & \multicolumn{7}{|c|}{ Enzyme activities } \\
\hline & & \multicolumn{3}{|c|}{$\begin{array}{c}\text { Glucose 6-phosphate } \\
\text { dehydrogenase }(E C 1.1 .149)\end{array}$} & \multicolumn{2}{|c|}{$\begin{array}{c}\text { Malic } \\
\text { enzyme }(E C 1.1 .1 .40)\end{array}$} & \multicolumn{2}{|c|}{$\begin{array}{l}\text { Fatty acid } \\
\text { synthetase }\end{array}$} \\
\hline & & Mean & & SD & Mean & SD & Mean & SD \\
\hline \multicolumn{9}{|l|}{ Expt 1} \\
\hline $0 / 93.9$ & 8 & $155^{\mathrm{b}}$ & & $14 \cdot 2$ & $119^{b}$ & $16 \cdot 7$ & $39 \cdot 1^{b}$ & $17 \cdot 2$ \\
\hline $93 \cdot 9 / 0$ & 8 & $90 \cdot 3^{a}$ & & $10 \cdot 1$ & $91 \cdot 8^{a}$ & 16.8 & $20 \cdot 9^{\mathrm{a}}$ & 6.8 \\
\hline Pooled SD & & \multicolumn{3}{|c|}{$12 \cdot 2$} & \multicolumn{2}{|c|}{$16 \cdot 8$} & \multicolumn{2}{|c|}{$13 \cdot 1$} \\
\hline $\mathrm{df}$ & & \multicolumn{3}{|c|}{14} & \multicolumn{2}{|c|}{14} & \multicolumn{2}{|c|}{14} \\
\hline \multicolumn{9}{|l|}{ Expt 2} \\
\hline $0 / 93.9$ & 7 & $204^{\mathrm{c}}$ & & $19 \cdot 8$ & $103^{c}$ & $15 \cdot 1$ & $31 \cdot 1^{\mathrm{b}}$ & 6.7 \\
\hline $28 \cdot 2 / 65 \cdot 7$ & 7 & $103^{b}$ & & 11.0 & $92 \cdot 7^{\mathrm{bc}}$ & $22 \cdot 2$ & $33 \cdot 3^{b}$ & 7.9 \\
\hline $65 \cdot 7 / 28 \cdot 2$ & 7 & $83.5^{\mathrm{a}}$ & & $16 \cdot 0$ & $87 \cdot 0^{\mathrm{ab}}$ & 14.6 & $24 \cdot 6^{\mathrm{a}}$ & 5.4 \\
\hline $93 \cdot 9 / 0$ & 7 & $76 \cdot 7^{\mathrm{a}}$ & & 17.7 & $70.4^{a}$ & 15.6 & $20 \cdot 2^{\mathrm{a}}$ & $4 \cdot 1$ \\
\hline Pooled SD & & \multirow{2}{*}{\multicolumn{3}{|c|}{$\begin{array}{l}16 \cdot 4 \\
24\end{array}$}} & \multicolumn{2}{|c|}{17.2} & \multicolumn{2}{|c|}{6.2} \\
\hline df & & & & & & & & \\
\hline
\end{tabular}

a,b,c Mean values within a column, within each experiment not sharing a common superscript letter were significantly different, $P<0.05$.

*For details of diets and procedures, see pp. 108-111.

experiment was also $40 \%$ higher in rats fed on diacylglycerol than in those fed on triacylglycerol. In Expt 2 the rates of mitochondrial and peroxisomal oxidation of palmitoyl-CoA increased as the dietary level of diacylglycerol increased. The replacement of triacylglycerol by diacylglycerol to supply more than $65.7 \mathrm{~g}$ fatty acids/ $\mathrm{kg}$ of the diet was required to obtain apparent physiological activity of dietary diacylglycerol in these variables.

Table 5 shows the activities of various enzymes involved in the $\beta$-oxidation pathway in rats fed on the diets containing varying amounts of diacylglycerol (Expt 2). The supernatant fraction obtained after centrifugation of liver homogenates at $500 \mathrm{~g}$ for $10 \mathrm{~min}$ was used to measure the activities of fatty acid oxidation enzymes except for carnitine palmitoyltransferase and acyl-CoA dehydrogenase; these were assayed in isolated mitochondrial fraction. The amounts of mitochondrial protein recovered from the $500 \mathrm{~g}$ supernatant fraction were comparable among the various groups $(19.2-20.5 \mathrm{mg} / \mathrm{g}$ liver). The activity of carnitine palmitoyltransferase, which regulates the rate of transport of fatty acids across the mitochondrial membrane, measured either radiochemically using intact mitochondria as an enzyme source (carnitine palmitoyltransferase I) or spectrophotometrically using the Triton-solubilized preparation of mitochondria increased as the dietary level of diacylglycerol increased. Dietary diacylglycerol also increased the activities of various enzymes involved in the fatty acid $\beta$-oxidation cycle (acyl-CoA dehydrogenase, acyl-CoA oxidase, enoyl-CoA hydratase and 3-hydroxyacyl-CoA dehydrogenase) dosedependently. In general, significant increases in the activities of carnitine palmitoyltransferases and enzymes involved in the fatty acid $\beta$-oxidation cycle were observed when triacylglycerol was replaced by diacylglycerol to supply more than $65.7 \mathrm{~g}$ fatty acids $/ \mathrm{kg}$ of the diet. 
Table 4. Rate of oxidation of palmitoyl-CoA substrate (nmol/min per $m$ g protein) in homogenates of the livers of rats fed on diets containing different proportions of diacylglycerol and triacylglycerol*

(Mean values and standard deviations)

\begin{tabular}{|c|c|c|c|c|c|}
\hline \multirow{3}{*}{$\begin{array}{l}\text { Dietary fatty acids } \\
\text { as diacylglycerol/ } \\
\text { triacylglycerol } \\
\text { (g/kg diet) }\end{array}$} & \multirow[b]{3}{*}{$n$} & \multicolumn{4}{|c|}{ Rate of oxidation of palmitoyl-CoA } \\
\hline & & \multicolumn{2}{|c|}{ Mitochondrial } & \multicolumn{2}{|c|}{ Peroxisomal } \\
\hline & & Mean & SD & Mean & SD \\
\hline \multicolumn{6}{|l|}{ Expt 1} \\
\hline $0 / 93.9$ & 8 & $1.63^{\mathrm{a}}$ & 0.16 & $3 \cdot 51^{\mathrm{a}}$ & 0.23 \\
\hline $93.9 / 0$ & 8 & $2 \cdot 07^{b}$ & 0.20 & $5 \cdot 13^{\mathrm{b}}$ & 0.45 \\
\hline Pooled SD & \multicolumn{3}{|c|}{0.18} & \multicolumn{2}{|c|}{0.36} \\
\hline df & \multicolumn{3}{|c|}{14} & \multicolumn{2}{|c|}{14} \\
\hline \multicolumn{6}{|l|}{ Expt 2} \\
\hline $0 / 93.9$ & 7 & $2 \cdot 07^{\mathrm{a}}$ & 0.13 & $3.33^{\mathrm{a}}$ & 0.28 \\
\hline $28 \cdot 2 / 65 \cdot 7$ & 7 & $2 \cdot 12^{\mathrm{a}}$ & 0.32 & $3.63^{\mathrm{a}}$ & 0.64 \\
\hline $65 \cdot 7 / 28 \cdot 2$ & 7 & $2.49^{\mathrm{b}}$ & 0.37 & $4 \cdot 35^{b}$ & 0.51 \\
\hline $93.9 / 0$ & 7 & $2 \cdot 66^{b}$ & 0.17 & $4.98^{b}$ & 0.61 \\
\hline Pooled SD & & \multirow{2}{*}{\multicolumn{2}{|c|}{$\begin{array}{c}0.27 \\
24\end{array}$}} & \multirow{2}{*}{\multicolumn{2}{|c|}{$\begin{array}{c}0.53 \\
24\end{array}$}} \\
\hline df & & & & & \\
\hline
\end{tabular}

${ }^{\mathrm{a}, \mathrm{b}}$ Mean values within a column within each experiment with unlike superscript letters were significantly different, $P<0.05$

*For details of diets and procedures, see pp. 108-111

We also measured the activities of auxiliary enzymes (2,4-dienoyl-CoA reductase and $\Delta^{3}, \Delta^{2}$-enoyl-CoA isomerase) involved in the pathway to degrade unsaturated fatty acids having cis double bond(s) via the $\beta$-oxidation pathway to yield acetyl-CoA. Dietary diacylglycerol also increased the activities of these auxiliary enzymes. The extent of the increase was more prominent in reductase than in isomerase.

The activities of marker enzymes for cell organelles (succinate dehydrogenase, catalase, NADPH-cytochrome $\mathrm{C}$ reductase and lactate dehydrogenase as markers for mitochondria, peroxisomes, microsomes and cytosols respectively) were measured in Expt 1 but no significant differences between rats fed on triacylglycerol and diacylglycerol were found in the activities of these enzymes (results not shown). In Expt 2 we measured the activity of a marker enzyme for mitochondria (succinate dehydrogenase) using both the $500 \mathrm{~g}$ supernatant fraction and isolated mitochondria as the enzyme sources. The activity of the enzyme measured in the $500 \mathrm{~g}$ supernatant fraction was comparable among groups $(51.6-57.5 \mathrm{nmol} / \mathrm{min}$ per $\mathrm{mg}$ protein). Values obtained in isolated mitochondria (269$293 \mathrm{nmol} / \mathrm{min}$ per $\mathrm{mg}$ protein) were approximately 5-6 times higher than those measured in the $500 \mathrm{~g}$ supernatant fractions. The activity of succinate dehydrogenase recovered in isolated mitochondrial fraction accounted for $77-81 \%$ of that found in the $500 \mathrm{~g}$ supernatant fraction among groups (differences were not statistically significant).

The replacement of dietary triacylglycerol with diacylglycerol increased the proportion of linoleic acid accompanying the decrease in the proportion of oleic acid in liver triacylglycerol in both Expts 1 and 2 (Table 6). Dietary diacylglycerol did not alter the proportion of linoleic acid but increased that of a derivative (arachidonic acid) in liver phospholipid in both Expts 1 and 2. Also, proportions of docosapentaenoic and docosahexaenoic acids in liver phospholipid were slightly but significantly higher in rats fed on the diet containing acylglycerol exclusively as diacylglycerol than in those fed on 


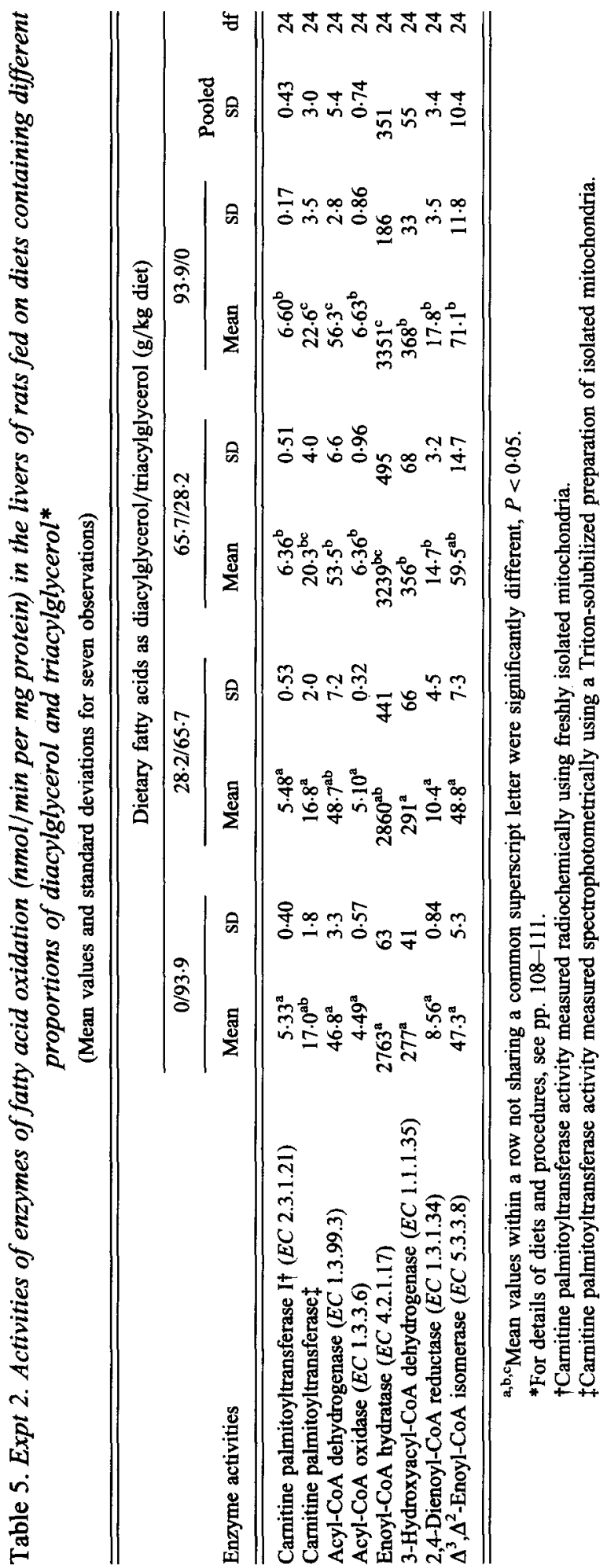




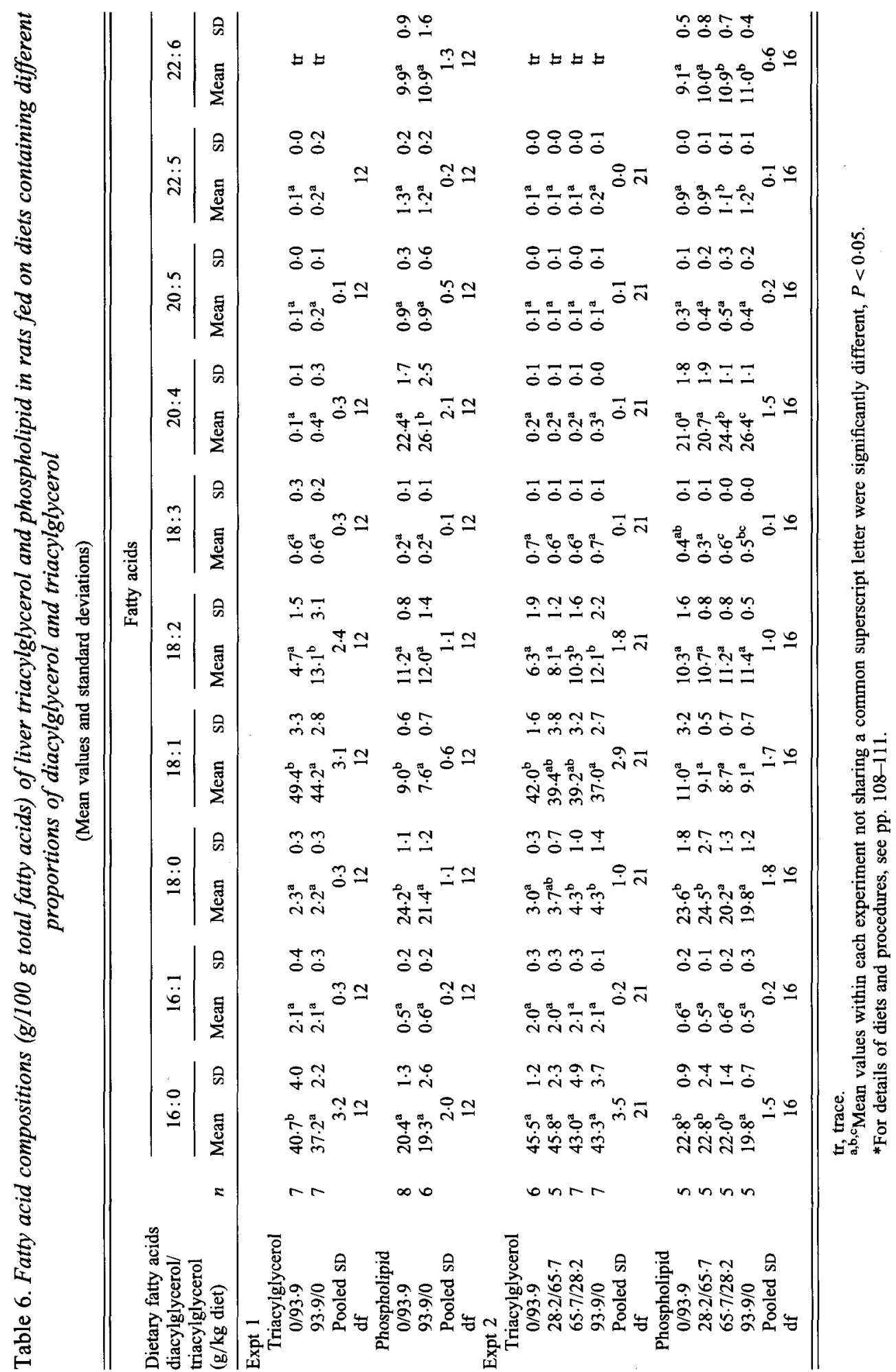


the diet without diacylglycerol or the diet containing $23.2 \mathrm{~g}$ fatty acids as diacylglycerol in Expt 2. No such differences were, however, detected in Expt 1. On the contrary, dietary diacylglycerol decreased the proportions of saturated fatty acids (palmitic and stearic acids) and oleic acid in the phospholipid fraction both in Expts 1 and 2.

\section{DISCUSSION}

The effect of dietary diacylglycerol in lowering serum triacylglycerol (Hara et al. 1993) was confirmed in the present study regardless of the feeding period ( 2 and 3 weeks for Expts 1 and 2 respectively). Moreover, the present study provided evidence that the alterations in the rates of fatty acid synthesis and oxidation in the liver, in addition to the modification in chylomicron assembly and secretion in the small intestine (Murata et al. 1994) are the factors by which dietary diacylglycerol reduces concentrations of triacylglycerol in serum. Dietary diacylglycerol also decreased the concentration of triacylglycerol in the liver, but increased that of cholesterol in this tissue in the present study. Thus, there is the possibility that dietary diacylglycerol not only modifies the rates of synthesis and degradation of fatty acid but also those of cholesterol in the liver.

Evidence supports the idea that the rates of fatty acid synthesis and oxidation in the liver are inversely related to each other under various nutritional and pathological conditions. Fasting (Ide et al. 1980) and experimental diabetes (Nepokroeff et al. 1974) reduce the rate of fatty acid synthesis but increase the rate of fatty acid oxidation in the liver (Mayes \& Felts, 1967; Van Harken et al. 1969). Dietary fish oil decreases the rate of ${ }^{3} \mathrm{H}_{2} \mathrm{O}$ incorporation into fatty acids but increases ketone body production in the perfused rat liver (Wong et al. 1984). A wealth of studies also indicate that fish oil increases the rate of fatty acid oxidation in rat liver peroxisomes (Halminski et al. 1991; Rustan et al. 1992). These nutritional and pathological conditions all accompany the reduction in the rate of VLDL production in the liver (Mayes \& Felts, 1967; Van Harken et al. 1969; Wong et al. 1984). Conversely, feeding (Ide et al. 1980) and treatment of diabetes by insulin (Nepokroeff et al. 1974) enhance the rate of fatty acid synthesis but decrease the rate of fatty acid oxidation accompanying the increase in the rate of VLDL production in the liver (Mayes \& Felts, 1967; Van Harken et al. 1969). In the present study, reciprocal responses in enzymes of fatty acid synthesis and oxidation in the liver were observed between rats fed on diacylglycerol and triacylglycerol. It is therefore probable that dietary diacylglycerol compared with triacylglycerol modifies rates of fatty acid synthesis and oxidation in vivo in the liver and these changes contribute to the serum triacylglycerol-lowering effect of this dietary lipid through the modification of the rate of lipoprotein production by the liver.

We measured the rates of mitochondrial and peroxisomal $\beta$-oxidation of palmitoyl$\mathrm{CoA}$ using the $500 \mathrm{~g}$ supernatant fraction of liver homogenates under the respective conditions for these pathways established by Mannaerts et al. (1979) in the present study. They found that mitochondrial activity was stimulated by albumin, but that it severely inhibited peroxisomal activity. We therefore did not include albumin in the measurement of peroxisomal activity but it was added to the assay medium $(7.2 \mathrm{mg} / \mathrm{ml})$ to measure mitochondrial activity. Under these conditions, Mannaerts et al. (1979) reported that peroxisomal activity was three times higher than mitochondrial activity in rats fed on a laboratory chow. Clofibrate feeding progressively increased peroxisomal activity so that it became ten times higher than the mitochondrial activity in rats fed on this drug (Mannaerts et al. 1979). The result of their experiment using isolated hepatocytes, however, indicated that the contribution of peroxisomes to fatty acid oxidation was less than $10 \%$ in both cells from control and clofibrate-fed rats. Although peroxisomal activity measured in the 
absence of albumin was also considerably higher than mitochondrial activity measured in the presence of albumin $(7.2 \mathrm{mg} / \mathrm{ml})$ in various groups of rats in the present study, it should be stated that the rate of peroxisomal and mitochondrial oxidation of fatty acid in the liver homogenates under the conditions employed in the present study does not necessarily represent the actual in vivo rate in these cell organelles. Dietary diacylglycerol compared with triacylglycerol not only increased the rate of oxidation of palmitoyl-CoA substrate in liver homogenates but also increased the activities of various enzymes involved in the $\beta$-oxidation of fatty acid. Dietary diacylglycerol did not increase the activities of marker enzymes for mitochondria (succinate dehydrogenase) and peroxisomes (catalase), so this dietary lipid may specifically induce enzymes in the $\beta$-oxidation pathway without accompanying the proliferation of these cell organelles.

The degradation of unsaturated fatty acids via the $\beta$-oxidation pathway to yield acetyl$\mathrm{CoA}$ requires the involvement of several auxiliary enzymes in addition to those required for the $\beta$-oxidation of saturated fatty acids (Osmundsen \& Hovik, 1988; Schulz, 1991, 1994). 2,4-Dienoyl-CoA reductase and $\Delta^{3}, \Delta^{2}$-enoyl-CoA isomerase are enzymes located in both mitochondria and peroxisomes (Dommes et al. 1981; Käki et al. 1987; Palosaari et al. 1990; Hakkola et al. 1994) and are required for the degradation by the $\beta$-oxidation pathway of unsaturated fatty acids having double bonds at even-numbered and odd-numbered positions respectively (Dommes et al. 1981; Käki et al. 1987; Osmundsen \& Hovik, 1988; Schulz; 1991, Hakkola et al. 1994). It has been reported that experimental conditions which induce the $\beta$-oxidation pathway, such as diabetes (Osmundsen \& Björnstad, 1985) and the administration of clofibrate (Dommes et al. 1981; Hakkola et al. 1994), and partially hydrogenated marine oil (Borrebaek et al. 1980) increased the activity of 2,4-dienoyl-CoA reductase in the rat liver. Also, there is evidence to indicate that clofibrate feeding increases $\Delta^{3}, \Delta^{2}$-enoyl-CoA isomerase activity in both mitochondria and peroxisomes (Palosaari et al. 1990; Hakkola et al. 1994). In the present study, dietary diacylglycerol compared with triacylglycerol not only increased the activities of carnitine palmitoyltransferase and various enzymes involved in the $\beta$-oxidation cycle but also those of 2,4-dienoyl-CoA reductase and $\Delta^{3}, \Delta^{2}$-enoyl-CoA isomerase. These auxiliary enzymes may therefore be controlled in coordination with other $\beta$-oxidation enzymes under various nutritional and pathological conditions.

Dietary diacylglycerol compared with triacylglycerol significantly modified the fatty acid compositions of triacylglycerol and phospholipid in the liver in spite of the fact that the fatty acid compositions of these dietary lipids were comparable. The reduction by dietary diacylglycerol in the rate of fatty acid synthesis as expected from reductions in the activities of enzymes in this pathway may increase the relative availability of linoleic acid of dietary origin as the substrate for enzymes involved in glycerolipid biosynthesis and in fatty acid desaturation and elongation. This consequence may increase the proportion of linoleic acid in liver triacylglycerol and that of arachidonic acid in the phospholipid fraction as observed in rats fed on diacylglycerol in the present study. The proportions of derivatives of $\alpha$-linolenic acid (docosapentaenoic and docosahexaenoic acids) also slightly but significantly increased in liver phospholipid of rats fed on diets containing 65.7 and $93.8 \mathrm{~g}$ fatty acids $/ \mathrm{kg}$ in the form of diacylglycerol relative to that in the animals fed on the diet devoid of diacylglycerol in Expt 2 . Thus, the relative availability of $\alpha$-linolenic acid for enzymes in fatty acid desaturation and elongation may also be augmented in the livers of rats fed on diacylglycerol. The increased availability of polyunsaturated fatty acids relative to other fatty acids through the depression in the rate of fatty acid synthesis may also account for the observed increases in the activities of 2,4-dienoyl-CoA reductase and $\Delta^{3}, \Delta^{2}$-enoyl-CoA isomerase in the liver of rats fed on diacylglycerol. 
Malonyl-CoA mediated inhibition of carnitine palmitoyltransferase represents a mechanism by which mitochondrial oxidation of long-chain fatty acids is regulated (Schulz, 1991). As malonyl-CoA is the enzyme product of acetyl-CoA carboxylase, its concentration in the liver decreases proportionally as the rate of fatty acid synthesis decreases (Boyd et al. 1981; Malewiak et al. 1985; Schulz, 1991). In the present study, dietary diacylglycerol compared with triacylglycerol at least decreased the activities of some lipogenic enzymes, indicating that this dietary lipid decreased fatty acid synthesis in the liver. Although we did not measure the activity of acetyl-CoA carboxylase in the present study, it is probable that this dietary lipid also decreases the activity of this enzyme in the liver. Thus, it is probable that the dietary diacylglycerol mediated inhibition of fatty acid synthesis accompanies the reduction in malonyl-CoA concentrations in the liver and thus augments fatty acid oxidation more than that expected from the increases in the activities of various enzymes in fatty acid oxidation. Measurements of the activity of acetyl-CoA carboxylase and hepatic concentration of malonyl-CoA in rats fed on diacylglycerol is required to clarify this point.

In conclusion, dietary diacylglycerol compared with triacylglycerol decreased the activities of enzymes of fatty acid synthesis but increased those of enzymes involved in the fatty acid oxidation pathway in rat liver Thus, alteration in fatty acid metabolism in the liver may be a crucial factor responsible for the serum triacylglycerol-lowering effect of diacylglycerol in the rat.

\section{REFERENCES}

American Institute of Nutrition (1977). Report of the American Institute of Nutrition ad hoc committee on standards for nutritional studies. Journal of Nutrition 107, 1340-1348.

Barron, E. J. \& Hanahan, D. J. (1958). Observation on the silicic acid chromatography of the neutral lipids of rat liver, beef liver and yeast. Journal of Biological Chemistry 231, 493-503.

Borrebaek, B., Osmundsen, H., Christiansen, E. N. \& Bremer, J. (1980) Increased 4-enoyl-CoA reductase activity in liver mitochondria of rats fed high-fat diets and its effect on fatty acid oxidation and the inhibitory action of pent-4-enoate. FEBS Letters 121, 23-24.

Boyd, M. E., Albright, E. B., Foster, D. W. \& McGary J. D. (1981). In vivo reversal of the fasting state of liver metabolism in the rat. Journal of Clinical Investigation 68, 142-152.

Bremer, J., Woldegiorgis, G., Schhalinske, K. \& Shrago, E. (1985). Carnitine palmitoyltransferase. Activation by palmitoyl-CoA and inactivation by malonyl-CoA. Biochimica et Biophysica Acta 833, 9-16.

Brunengraber, H., Boutry, M. \& Lowenstein, J. M. (1973). Fatty acid and 3- $\beta$-hydroxysterol synthesis in the perfused rat liver. Journal of Biological Chemistry 248, 2656-2669.

Cohen, G., Dembiec, D. \& Marcus, J. (1970). Measurement of catalase activity in tissue extract. Analytical Biochemistry 34, 30-38.

Dommes, V., Baumgart, C. \& Kunau, W.-H. (1981). Degradation of unsaturated fatty acids in peroxisomes. Existence of 2,4-dienoyl-CoA reductase pathway. Journal of Biological Chemistry 256, 8259-8262.

Dommes, V. \& Kunau, W.-H. (1976). A convenient assay for acyl-CoA dehydrogenase. Analytical Biochemistry 71, 571-578.

Folch, J., Lees, M. \& Sloane-Stanley, G. H. (1957). A simple method for the isolation and purification of total lipids from animal tissue. Journal of Biological Chemistry 226, 497-509.

Goldman, P. \& Vagelos P. R. (1961). The specificity of triglyceride synthesis from diglycerides in chicken adipose tissue. Journal of Biological Chemistry 236, 2620-2623.

Hakkola, E. H., Hiltunen J. K. \& Autio-Harmainen, H. I. (1994). Mitochondrial 2,4-dienoyl-CoA reductases in the rat: differential responses to clofibrate treatment. Journal of Lipid Research 35, 1820-1828.

Halminski, M. A., Marsh, J. B. \& Harrison, E. H. (1991). Differential effects of fish oil, safflower oil and palm oil on fatty acid oxidation and glycerolipid synthesis in rat liver. Journal of Nutrition 121, 1554-1561.

Hara, K., Onizawa, K., Honda, H., Otsuji, K., Ide, T. \& Murata, M. (1993). Dietary diacylglycerol-dependent reduction in serum triacylglycerol concentration in rats. Annals of Nutrition and Metabolism 37, 185-191.

Hashimoto, T., Miyazawa, S., Gunarso, D. \& Furuta, S. (1981). $\alpha$-Amanitin inhibits the oxidation of long-chain fatty acids in mouse liver. Journal of Biochemistry 90, 415-421.

Hsu, R. Y. \& Lardy, H. A. (1969). Malic enzyme. Methods in Enzymology 13, 230-235.

Ide, T., Gotoh, Y. \& Sugano, M. (1980). Dietary regulation of hepatic 3-hydroxy-3-methylglutaryl-CoA reductase and cholesterol synthetic activities in fasted-refed rats. Journal of Nutrition 110, 158-168. 
Ide, T., Hirabayashi, S., Kano S. \& Sugano, M. (1992). Soybean phospholipid dependent reductions in triacylglycerol concentration and synthesis in the liver of fasted-refed rats. Biochimica et Biophysica Acta 1124, 163-170.

Ide, T., Kano, S., Murata, M., Yanagita, T. \& Sugano, M. (1994). Dietary modifications of the biliary bile acid glycine : taurine ratio and activity of hepatic bile acid-CoA : amino acid $N$-acyltransferase $(E C 2.3 .1)$ in the rat. British Journal of Nutrition 72, 93-100.

Ide, T., Okamatsu, H. \& Sugano, M. (1978). Regulation by dietary fats of 3-hydroxy-3-methylglutarylcoenzyme A reductase in rat liver. Journal of Nutrition 108, 601-612.

Ide, T., Oku, H. \& Sugano, M. (1982). Reciprocal responses to clofibrate in ketogenesis and triglyceride and cholesterol secretion in isolated rat liver. Metabolism 31, 1065-1072.

Ide, T. \& Ontko, J. A. (1981). Increased secretion of very low density lipoprotein triglyceride following inhibition of long chain fatty acid oxidation in isolated rat liver. Journal of Biological Chemistry 256, 1024710255.

Ide, T., Watanabe, M., Sugano M. \& Yamamoto, I. (1987). Activities of liver mitochondrial and peroxisomal fatty acid oxidation enzymes in rats fed trans fat. Lipids 22, 6-10.

Käki, T., Hakkola, E., Hassinen, I. E. \& Hiltunen, J. K. (1987). $\beta$-Oxidation of polyunsaturated fatty acids in peroxisomes. Subcellular distribution of $\Delta^{3}, \Delta^{2}$-enoyl-CoA isomerase activity in rat liver. FEBS Letters 215 , 228-232.

Karlson, K. A. \& Pascher, I. (1971). Thin layer chromatography of ceramides. Journal of Lipid Research 12, $466-472$.

Kawaguchi, A., Yoshimura, T. \& Okuda, S. (1981). A new method for the preparation of acyl-CoA thioesters. Journal of Biochemistry 89, 337-339.

Kelley, D. S. \& Kletzien, R. F. (1984). Ethanol modulation of hormonal and nutritional regulation of glucose 6phosphate dehydrogenase activity in primary cultures of rat hepatocytes. Biochemical Journal $217,543-549$.

Kelley, D. S., Nelson, G. J. \& Hunt, J. E. (1986). Effect of prior nutritional status on the activity of lipogenic enzymes in primary monolayer cultures of rat hepatocytes. Biochemical Journal 235, 87-90.

Kunau, W.-H. \& Dommes, P. (1978). Degradation of unsaturated fatty acids. Identification of intermediates in the degradation of cis-4-decenoyl-CoA by extracts of beef-liver mitochondria. European Journal of Biochemistry 91, 533-544.

Malewiak, M.-I., Griglio, S. \& Le Liepvre, X. (1985). Relationship between lipogenesis, ketogenesis, and malonyl-CoA content in isolated hepatocytes from the obese Zucker rat adapted to a high-fat diet. Metabolism 34, 604-611.

Mannaerts, G. P., Debeer, L. J., Thomas, J. \& De Schepper, P. J. (1979). Mitochondrial and peroxisomal fatty acid oxidation in liver homogenate and isolated hepatocytes from control or clofibrate-treated rats. Journal of Biological Chemistry 254, 4585-4595.

Markwell, M. A. K., McGroarty, E. J., Bieber L. L. \& Tolbert, N. E. (1973). The subcellular distribution of carnitine acyltransferases in mammalian liver and kidney. A new peroxisomal enzyme. Journal of Biological Chemistry 248, 3426-3432.

Mayes, P. A. \& Felts, J. M. (1967). Regulation of fat metabolism in the liver. Nature 215, 716-718.

Murata, M., Hara, K. \& Ide, T. (1994). Alteration by diacylglycerols of the transport and fatty acid composition of lymph chylomicron in rats. Bioscience, Biotechnology and Biochemistry 58, 1416-1419.

Nepokroeff, C. M., Lakshmanan, M. R., Ness, G. C., Muesing, R. A., Kleinsek, A. \& Porter, J. W. (1974). Coordinate control of rat liver lipogenic enzymes by insulin. Archives of Biochemistry and Biophysics 162, 340-344.

Omura, T. \& Takesue, S. (1970). A new method for simultaneous purification of cytochrome b5 and NADPHcytochrome c reductase from rat liver microsomes. Journal of Biochemistry 67, 249-257.

Osmundsen, H. \& Björnstad, K. (1985). Inhibitory effect of some long-chain unsaturated fatty acids on mitochondrial $\beta$-oxidation. Biochemical Journal 230, 329-337.

Osmundsen, H. \& Hovik, R. (1988). $\beta$-Oxidation of polyunsaturated fatty acids. Biochemical Society Transactions 16, 420-422.

Osumi, T. \& Hashimoto, T. (1979a). Subcellular distribution of the enzymes of the fatty acyl-CoA $\beta$-oxidation system and their induction by di(2-ethylhexyl)phthalate in rat liver. Journal of Biochemistry 85, 131-139.

Osumi, T. \& Hashimoto, T. (1979b). Occurrence of two 3-hydroxyacyl-CoA dehydrogenases in rat liver. Biochimica et Biophysica Acta 574, 258-267.

Palosaari, P. M., Kilponen, J. M., Sormunen, R. T., Hassinen, I. E. \& Hiltunen, J. K. (1990). $\Delta^{3}, \Delta^{2}$-Enoyl-CoA isomerase. Characterization of the mitochondrial isoenzyme in the rat. Journal of Biological Chemistry 265, 3347-3353.

Rustan, A. C., Christiansen, E. N. \& Drevon, C. A. (1992). Serum lipid, hepatic glycerolipid metabolism and peroxisomal fatty acid oxidation in rats fed n-3 and n-6 fatty acids. Biochemical Journal 283, 333-339.

Schulz, H. (1991) Beta oxidation of fatty acids. Biochimica et Biophysica Acta 1081, 109-120.

Schulz, H. (1994) An overview of the pathway for the $\beta$-oxidation of polyunsaturated fatty acids. In Fatty Acids and Lipids: Biological Aspects, pp. 18-21 [C. Galli, A. P. Simopoulos and E. Tremoli, editors]. Basel: S. Karger AG. 
Snedecor, G. W. \& Cochran, W. G. (1989). Statistical Methods, 8th ed. Ames: Iowa University Press.

Van Harken, D. R., Dixon, C.W. \& Heimberg, M. (1969). Hepatic lipid metabolism in experimental diabetes. Journal of Biological Chemistry 244, 2278-2285.

Veeger, C., Der Vartanian, D.V. \& Zeylmaker, W. P. (1969). Succinate dehydrogenase. Methods in Enzymology 13, $81-90$.

Wahlefeld, A. W. (1985). Lactate dehydrogenase. UV-method with 1-lactate and NAD. In Methods of Enzymatic Analysis, 3rd English ed., vol. 8, pp. 126-133 [H. U. Bergmeyer, J. Bergmeyer and M. Graßl, editors]. Deerfield Beach: VHC Publishers.

Windmueller, H. G. \& Spaeth, A. E. (1967). De novo synthesis of fatty acid in perfused rat liver as a determinant of plasma lipoprotein production. Archives of Biochemistry and Biophysics 122, 362-369.

Wong, S. H., Nestel, P. J., Trimble, R. P., Storer, G. B., Illman, R. J. \& Topping, D. L. (1984). The adaptive effects of dietary fish and safflower oil on lipid and lipoprotein metabolism in perfused rat liver. Biochimica et Biophysica Acta 792, $103-106$. 